Nova Southeastern University

From the SelectedWorks of Florence Shu-Acquaye

2016

\title{
The Decline of HIV/Aids: A New Paradigm In Sub-Saharan Africa?
}

Florence Shu-Acquaye 


\section{HEINONLINE}

Citation:

Florence Shu-Acquaye, The Decline of HIV/AIDS: A New

Paradigm in Sub-Saharan Africa, 24 Afr. J. Int'l \&

Comp. L. 362 (2016)

Provided by:

Nova Southeastern University Law Library \& Technology Center

Content downloaded/printed from $\underline{\text { HeinOnline }}$

Wed Mar 7 09:57:36 2018

-- Your use of this HeinOnline PDF indicates your acceptance of HeinOnline's Terms and Conditions of the license agreement available at http://heinonline.org/HOL/License

-- The search text of this PDF is generated from uncorrected OCR text.

-- To obtain permission to use this article beyond the scope of your HeinOnline license, please use:

\section{Copyright Information}

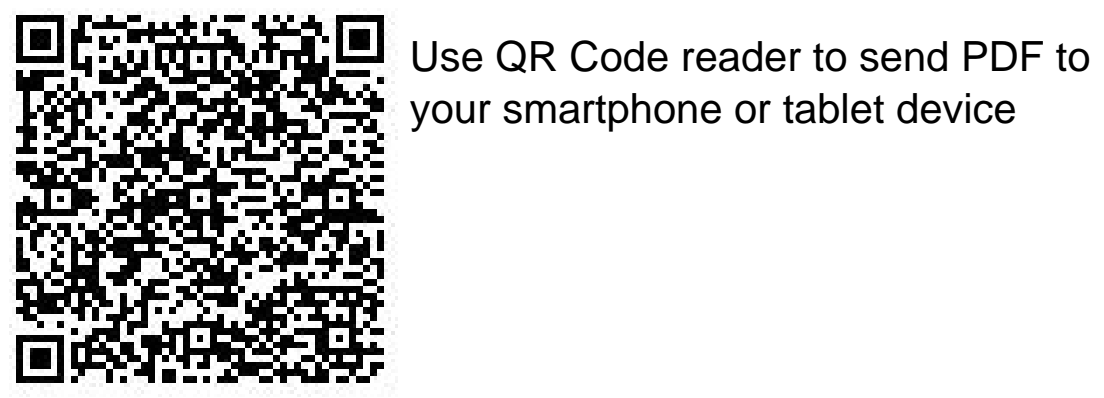




\title{
THE DECLINE OF HIV/AIDS: A NEW PARADIGM IN SUB-SAHARAN AFRICA?
}

\author{
FLORENCE SHU-ACQUAYE *
}

\section{INTRODUCTION}

That Sub-Saharan Africa is more heavily affected by HIV/AIDS than any other region of the world is no longer headline news. It is home to an estimated 24.7 million people living with HIV, representing around two-thirds of the global total. In 2013, around 1.2 million people died from AIDS and 1.5 million people became infected with HIV in Sub-Saharan Africa. Almost 15 million children have lost one or both parents to HIV/AIDS since the beginning of the epidemic. The devastating impact of the disease is clear at all levels from government to households: HIV/AIDS reverses life expectancy gains, erodes productivity, consumes savings, weakens growth efforts and threatens the realization of the Millennium Development Goals (MDG) in Africa. ${ }^{1}$

In spite of the vast and corrosive impact of the epidemic, an encouraging trend has been emerging from the reported statistics. The 2012 UNAIDS Report $^{2}$ on the global AIDS epidemic highlighted that in only 24 months, there had been a 60 percent jump in people accessing life-saving treatment with a corresponding drop in mortality. In 2014, 41 percent of all adults living with HIV had access to antiretroviral treatment, which is up by 23 percent in 2010. Between 2005 and 2013, the number of people dying from AIDS-related causes in Sub-Saharan Africa declined by 39 percent, from 1.8 million to 1.2 million. Additionally,

* Florence Shu-Acquaye is a Professor of Law at the Shepherd Broad College of Law in Nova Southeastern University, Fort Lauderdale, Florida. She teaches in the areas of business, international, comparative, and commercial law. She would like to thank her Research Assistants, Mario Brito and Gregory Lambert, for their great assistance

1 World Bank, The World Bank's Commitment to HIV/AIDS in Africa: Our Agenda for Action, 2007-2011 (Report) (March 2008).

2 Recognising the opportunity to plan for the end of AIDS, countries pledged in the United Nations Political Declaration on HIV and AIDS to intensify efforts to eliminate HIV and AIDS by taking specific steps to achieve the goals by 2015. See Joint United Nations Programme on HIV/AIDS (UNAIDS), Global Report: UNAIDS Report on the Global AIDS Epidemic (2012), available at http://www.unaids.org/en/media/unaids/contentassets/documents/epidemiology/2012/gr2012/ 20121120_UNAIDS_Global_Report_2012_en.pdf (visited April 2012). See also UNAIDS Facts Sheet 2015 available at http:/www.unaids.org/sites/default/files/en/media/unaids/contentassets/ documents/factsheet/2014/20140716_FactSheet_en.pdf.

African Journal of International and Comparative Law 24.3 (2016): 362-388 Edinburgh University Press

DOI: $10.3366 /$ ajicl.2016.0159

(C) Edinburgh University Press

www.euppublishing.com/loi/ajicl 
there has been a 25 percent decline in new infections in the decade between 2001 and $2011 .^{3}$ The new infection rate has fallen by 50 percent or more in 25 countries worldwide (13 in Sub-Saharan Africa), with some of the most dramatic improvements seen in African countries with very high prevalence rates: 73 percent drop in Malawi, 71 percent in Botswana, 68 percent in Namibia, 58 percent in Zambia, 50 percent in Zimbabwe, 41 percent in South Africa, and 37 percent in Swaziland (the country with the highest HIV-prevalence rate in the world). ${ }^{4}$ Even more encouragingly, the population experiencing half of all the reductions in HIV infection rates in the last two years has been children. Six African countries - Burundi, Kenya, Namibia, South Africa, Togo, and Zambia - saw at least a 40 percent reduction in the number of children newly infected by the virus between 2009 and 2011.5 In 2011, coverage of services to prevent mother-to-child transmission (PMTCT) of HIV in Sub-Saharan Africa reached 59 percent. All of this has contributed to Sub-Saharan Africa reducing AIDS-related deaths by 59 percent in the last two years alone. ${ }^{6}$

However, there are critics who challenge the above findings, and argue that UNAIDS statistics paint a rosy picture, essentially covering the fact that the remarkable gains of recent years have yet to be consolidated and spread. For example, at the same time that the highest-impacted countries were reducing transmission rates, 11 countries in Sub-Saharan Africa saw more modest declines, between 1 and 19 percent. In four countries - Angola, Congo, Equatorial Guinea, Guinea-Bissau-the number of new HIV infections among children actually increased. Furthermore, many prevention 'success stories,' when analyzed under a closer lens, turn out to be much less effective than presented. For example, during the 1990s, an ambitious HIV prevention campaign carried out in a South African gold-mining community was held up as a model for the rest of Africa. Health workers raised awareness about HIV using community meetings, drama, and music; condoms were liberally distributed in public places; and treatment services for other sexually transmitted diseases, which make it easier for HIV to spread, were greatly improved. However, in the long run the campaign had no measurable effect on HIV transmission rates.

3 Ibid.

4 Michel Sidibe, Forward to UNAIDS, Global Report: UNAIDS Report on the Global AIDS Epidemic (UNAIDS, 2012).

5 Africa Rev., Powered by Nation Media Grp., Kenya, available at http://www.businessdaily africa.com/HIV-prevalence-highest-among-the-educated-and-women-/-/539546/1987422. This reduction has been accelerated by rapid progress made by giving more women living with HIV access to prevention and treatment services. See also UNAIDS, UNAIDS World AIDS Day Report (2012).

6 Sidibé, supra, note 4, at p. 5.

7 See Helen Epstein, The Invisible Cure: Why We Are Losing the Fight Against AIDS in Africa (Picador, 2008). Epstein pinpoints the failure of 'misguided, moneyed donors and public-health officials who try to impose their agendas - condom promotion, abstinence, treating other sexually transmitted diseases, microloans - without paying close enough attention to local realities [and perhaps] inadvertently reinforce[ing] the stigma, shame and prejudice surrounding the disease' as causing the ineffectiveness of the program. 
In order to sustain the recent gains in combating HIV/AIDS, it is important to research and evaluate the dynamics behind the positive data trends in order to understand which specific changes and policies were key, and how these changes can be consolidated and emulated in other regions. This would establish a pathway to curbing or even eradicating HIV/AIDS in the foreseeable future.

My past research has explored women and HIV/AIDS in Africa, addressing the issues behind women's increased vulnerability in contracting HIV/AIDS on the continent, and on how to address such a disproportionately high rate of infection. ${ }^{8}$ Having conducted a major research project on this subject in 2004 to 2006, almost ten years later I now believe that the time is ripe to turn a retrospective and analytical eye on the progresses made in fighting the disease. ${ }^{9}$ Assessing where the continent stands today is particularly vital in a context of the fast-approaching United Nations goal in curbing the AIDS pandemic by 2015.

This article examines the African countries that have made significant progress in reducing new HIV infections, rates of prevalence, AIDS-related deaths, transmissions from mother to child, and any other gains in limiting the impact of this disease. The goal is to pinpoint the factors that propel these trends, and to then determine whether and how they can be implemented in other regions or countries through an in-depth analysis of effective and pragmatic approaches in

8 Some articles that I have published in this area include: Florence Shu-Acquaye, The 'Legal Implications of Living with HIV/AIDS in a Developing Country: The African Story,' 32 Syracuse Journal of International Law and Commerce (2004): 51-81; Florence Shu-Acquaye, The Cameroonian Woman of the 21st Century: What Progress?, SWAA Magazine (2007); Florence Shu-Acquaye, 'Is There a Necessity for a Law to Deal with Persons Living with HIV/AIDS in Cameroon?' SWAA Magazine (2006); Florence Shu-Acquaye, 'Children, and HIV/AIDS in Africa: Hopes and Dreams through Education,' 4 Howard Human Rights and Globalization Law Review (2011): 87-132 (co-author was former high-school student, Gabrielle Roland); Florence Shu-Acquaye, 'Global Education on Sexuality: Improving Girls' Participation in Education and Its Positive Correlation on HIV,' SWAA ECHOS (2009); Florence Shu-Acquaye, 'United Nations Convention on the Elimination of All Forms of Discrimination against Women (CEDAW) and the African Woman: Progress in the Fight against HIV/AIDS in Southern Africa?' 8 University of Botswana Law Journal (2008); Florence Shu-Acquaye, Youths and HIV/AIDS in Africa: The Role of Education, 1 (2): Gender Section, Newsletter of the Commonwealth Magistrates and Judges' Association (2012); Florence Shu-Acquaye et al., Women, the Law and HIV/AIDS: A Conundrum for the Legislature in Africa? (Vandeplas Publishing, 2008).

9 I went on a sabbatical to Cameroon in the fall of 2006 and worked with the Society for Women and AIDS in Africa (SWAA), an African organization dedicated to addressing the problems faced by women with HIV/AIDS. I assisted this organization (the Yaoundé branch in Cameroon) principally by reviewing existing policies. For instance, I reviewed a proposed Model Law on STD/HIV/AIDS for West and Central Africa; I reviewed an 'Avant Projet de Loi Fixant Les Droits et Obligations Des Personnes Vivant avec Le VIH/SIDA' (Cameroon's proposed law on the rights and obligations of persons living with HIV/AIDS); I reviewed and made recommendations for the implementation of Articles 4, 5, and 14 of the United Nations Convention on the Elimination of All Forms of Discrimination Against Women (CEDAW) in Cameroon; and I drafted policies and laws that would regulate women with HIV/AIDS in critical areas, including but not limited to: inheritance law, marriage, and basic human rights relating to the rights of women living with HIV/AIDS. I interviewed a range of professionals (jurists, doctors, nurses, patients, and heads of NGOs) regarding policies and proposed laws on HIV/AIDS in Cameroon. Simultaneously, while writing a book entitled Women, the Law and HIV/AIDS: A Conundrum for the Legislature in Africa?, I also participated and acted as the representative of SWAA at several conferences, workshops, and seminars. I edited and wrote articles in the SWAA magazine and related publications. 
Africa. Given that adequate resources are a crucial component in dealing with HIV/AIDS, I also pay attention to the role of donor funding, with a focus on the Global Fund to Fight Aids, Tuberculosis, and Malaria, in addition to the President's Emergency Plan for Aids Relief (PEPFAR) ${ }^{10}$ I further seek to describe how the cultural values that traditionally stood in the way of efforts combating HIV/AIDS have been transformed in the last decade. I highlight the challenges likely to be encountered in emulating what works for one country in another, the lessons learned, as well as the role of the African governments in addressing these issues. Finally, I will analyze the extent to which Sub-Saharan African states have been able to leverage the flexibility of the Agreement on Trade Related Aspects of Intellectual Property Rights (TRIPS) to improve access to HIV/AIDS medicine for their citizens, and thus analyze whether this instrument can be considered part of the success story.

\section{A. Past and Current Trends of the Epidemic}

\section{Global and Sub-Saharan Trends 2002/3}

In 2002 HIV was the most prevalent infectious disease, and the most common cause of death in Africa. ${ }^{11}$ According to the World Health Organization/UNAIDS December 2002 report, HIV/AIDS was responsible for over 2.4 million deaths in Sub-Saharan Africa in the year 2002 $2^{12}$ and 2.3 million in 2003. ${ }^{13}$ This number was more than ten times the number of people who perished in wars and armed conflict during the same period (in Sub-Saharan Africa). At the end of 2002, more than 29.4 million adults and children, (close to one in ten adults between the ages of 15 and 49 years) were living with HIV/AIDS. This represented about 70 percent of the global total of 42 million persons living with HIV/AIDS. ${ }^{14}$

10 A United States government initiative and the largest funder of HIV efforts worldwide.

11 Diseases such as malaria and tuberculosis were also major causes of death in Africa. A coalition of governments and non-governmental organizations, led by the UN, launched the Global Fund Against AIDS, Tuberculosis, and Malaria in 2002, aimed at addressing these diseases. By August 2002 the total pledge to the fund was over $\$ 2$ billion, and it was estimated that a sizeable amount would be devoted towards AIDS. See Johannesburg Declaration on Sustainable Dev., 199/20 A, World Summit on Sustainable Dev., A/CONF.199/20 (4 September 2002).

12 In four southern African countries, national adult prevalence has risen to over 30 percent: Botswana has the highest prevalence at 38.8 percent; Lesotho at 31 percent; Swaziland at 33.4 percent; and Zimbabwe at 33.7 percent. UNAIDS and WHO, AIDS Epidemic Update (Report) (December 2002). Yet, looking back to 1982, Uganda was the only country in Africa with an adult HIV prevalence rate higher than 2 percent. See Africa Region: The World Bank, Intensifying Action Against HIV/AIDS in Africa, Responding to a Development Crisis, at 17 (June 1999), available at http://siteresources.worldbank.org/AFRICAEXT/Resources/aidstrat.pdf.

13 The 2003 UNAIDS and WHO estimates suggest that the number of people living with HIV/AIDS in Sub-Saharan Africa is lower than in 2002. This modest decrease may lead to a false belief that the number of people living with the virus has decreased in Africa, which is really not the case; rather, better data and understanding have enabled the UNAIDS secretariat and WHO to arrive at a better and more accurate estimate. Applying such improved data and understanding to past years shows a steady increase in the number of people living with HIV/AIDS in Sub-Saharan Africa. UNAIDS and WHO, AIDS Epidemic Update (Report) (December 2002).

14 Ibid. 


\section{Current Global and Sub-Saharan Trends 2012/14}

Globally, 36.9 million ( 34.3 million -41.4 million) people were living with HIV at the end of 2014. An estimated 0.8 percent of adults aged 15-49 years worldwide are living with HIV. Sub-Saharan Africa remains most severely affected, with nearly 1 in every 20 adults ( 4.9 percent) living with HIV and accounting for 69 percent of the people living with HIV worldwide. Worldwide, the number of people newly infected continues to fall: the number of people, adults and children, acquiring HIV infection in 2011 was 20 percent lower than in $2001 .{ }^{15}$ The sharpest declines in the number of people acquiring HIV infection since 2001 has occurred in the Caribbean (42 percent) and Sub-Saharan Africa (25 percent). Figure 1 shows the downward trend in the number of people newly infected in Sub-Saharan Africa from 2001 to 2012.

\section{B. Examining Categories for Progress}

Transformation of cultural values has been a major driver in decreasing the transmission of HIV/AIDS. For example, the circumcision of males is said to reduce sexual transmission of HIV.

\section{Male Circumcision}

There is compelling evidence that medical male circumcision reduces the propensity to transmit HIV sexually from women to men by 60 percent. ${ }^{16}$ Observational studies noted a significantly lower rate of HIV infection in countries where the practice of male circumcision is widespread. ${ }^{17}$ Information from the trials led the WHO and UNAIDS to issue guidelines on male circumcision as an HIV prevention intervention. ${ }^{18}$ Since voluntary male circumcision programs for HIV prevention started in 2007, an estimated two million men have undergone circumcision for prevention in Eastern and Southern Africa. ${ }^{19}$ UNAIDS believes that voluntary medical male circumcision has the potential to prevent an estimated one in five new HIV infections in the region by $2025 .{ }^{20}$ Consequently, WHO

15 UNAIDS, supra, note 2.

16 Press Release, UNAIDS, UNAIDS Welcomes Pre-Qualification by WHO of First Non-Surgical Device for Adult Male Circumcision in HIV Prevention Efforts (7 June 2013), available at http://www.unaids.org/sites/default/files/web_story/20130607_PS_VMMC_en_0.pdf.

17 In 2005 and 2006, three randomized control trials evaluated the impact of male circumcision on the risk of HIV infection in males. All three trials confirmed that male circumcision, when performed by well-trained medical professionals, is safe and reduces the risk of HIV infection. See Lance Gable et al., Legal Aspects of HIV/AIDS: A Guide for Policy and Law Reform (World Bank, 2007). The most recent data from Uganda shows that in the five years since the trial was completed, the men who were circumcised were 73 percent less likely to become infected with HIV. See WHO, HIV/AIDS, Voluntary Medical Male Circumcision for HIV Prevention (July 2012), available at http://www.who.int/hiv/topics/malecircumcision/fact_sheet/en/.

18 Ibid.

19 Press Release, supra, note 16.

20 Medical male circumcision provides partial protection to men from heterosexual transmission, thus WHO and UNAIDS recommend that it be practiced in combination with other approaches to prevent HIV infections that include the correct and consistent use of male and female condoms, a 

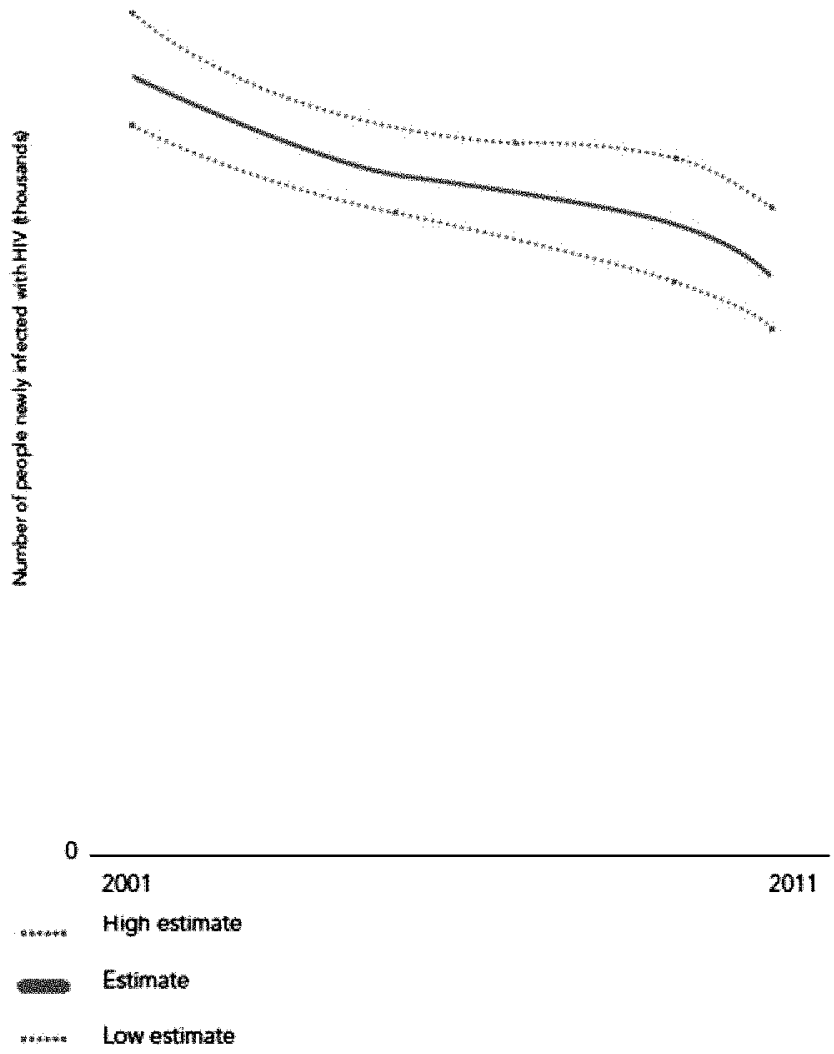

Figure 1. UNAIDS Report on the Global Aids Epidemic 2012.

and UNAIDS advise that 'countries considering introduction or expansion of male circumcision services should ensure that appropriate laws, regulations and policies are developed so that male circumcision services are accessible, provided safely and without discrimination. ${ }^{21}$ Ancillary problems raised by the guideline is the question of who carries out the circumcision-i.e. should it be traditional or religious health practitioners or medical doctors? - and at what age should the conduct be carried out - at birth, at adolescence, or at passage to manhood? To this effect, South Africa, for example, passed the Application of Health Standards

reduction in the number sexual partners, the promotion of safe sexual practices, and the treatment of sexually transmitted infections. Ibid.

21 See Gable et al., supra note 17, at p. 39. 
in Traditional Circumcision Act in Eastern Cape Province, with the goal of setting safety standards for traditional practitioners. ${ }^{22}$ In the same vein, South Africa's parliament added a section on male circumcision in its Children' Act, banning circumcision of males under the age of 16 years, except under certain circumstances. ${ }^{23}$ For children over 16 , informed consent and proper counseling in the prescribed manner are mandated. ${ }^{24}$

As of December 2012, 3.2 million African men had been circumcised through specific services for voluntary medical male circumcision. The number of men circumcised in 2012 virtually doubled, rising from 1.5 million as of December 2011. Attainment of the target, 20 million in 2015, is still a challenge. ${ }^{25}$ Progress has been noticeable in provinces prioritized for scale-up, for example in Ethiopia 57 percent of the coverage target, in Kenya 63 percent. Meanwhile, rates of less than 10 percent have been attained in Lesotho, Malawi, Namibia, Rwanda, and Zimbabwe where voluntary male circumcision was stated as a priority. ${ }^{26}$

In 2013, WHO prequalified the first adult circumcision device for use in low resource regions. The device, PrePex, needs no sutures or administration of injected local anesthetic, and can be placed and removed by trained mid-level health providers, including nurses. ${ }^{27}$ This, it is hoped, would accelerate scale-up efforts by providing men with an alternative as well as relieve the strains on the limited number of surgeons available in priority countries. ${ }^{28}$

Figures 2 and 3 highlight the progress in the annual number of voluntary medical male circumcisions in selected countries during 2009-12 and the progress towards 2015 targets of voluntary medical male circumcision, by December 2012, respectively. ${ }^{29}$

\section{Prevention of Mother-to-Child Transmission of HIV (PMTCT)}

Mother-to-child transmission of HIV can take place when the pregnant mother is infected with HIV while the fetus is in the womb, during childbirth, or while breastfeeding. Without any intervention, the risk of mother-to-child transmission is 20 to 40 percent. $^{30}$ The risk of HIV transmission can be potentially reduced by over 40 percent by the use of antiretroviral drugs. It becomes essential that the testing of the mother be done while still pregnant. However, while mandatory testing has a good public health justification, it is controversial as most policy-makers and healthcare providers reject mandatory HIV testing for pregnant women. ${ }^{31}$ The fear is that mandatory testing would discourage women

22 Ibid.

23 For religious purposes or medical reasons. Ibid.

24 Ibid.

25 UNAIDS, supra, note 2, at p. 18.

26 Ibid. Men in Sub-Saharan Africa are said to be at a higher risk of acquiring HIV when in their twenties and thirties, and therefore are at the top priority for scale-up. Ibid. at p. 20 .

27 Ibid.

28 Ibid.

29 UNAIDS, supra, note 2, at p. 19. Reproduced with permission.

30 Gable et al., supra, note 17 , at p. 7 .

31 Ibid. 

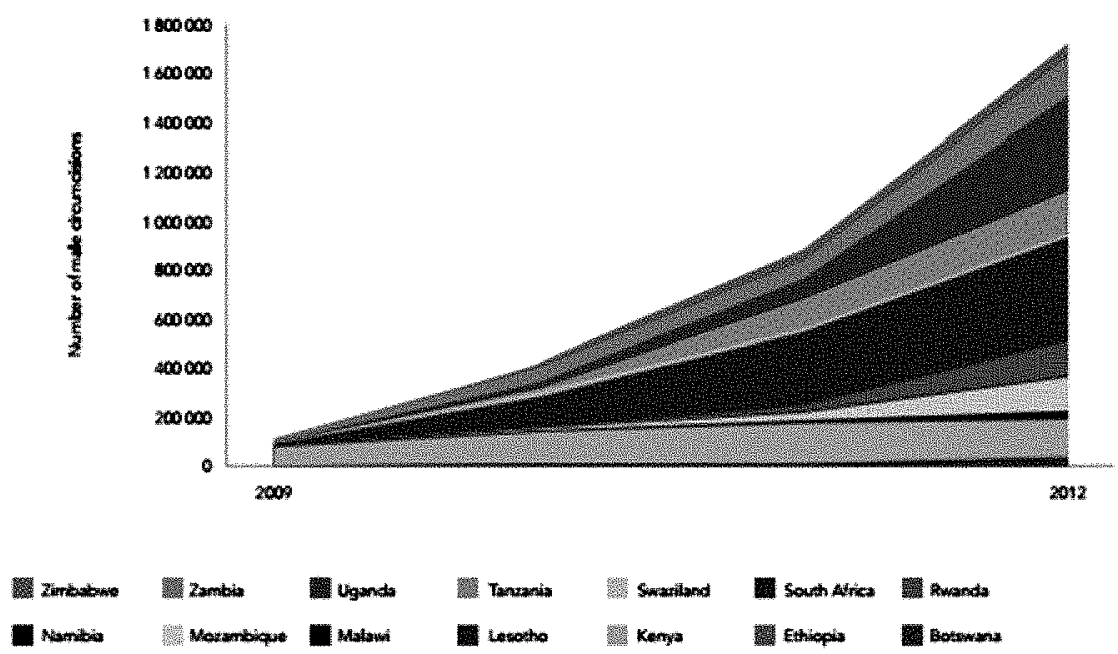

Figure 2. Annual number of voluntary medical male circumcisions, selected countries, 2009-12.

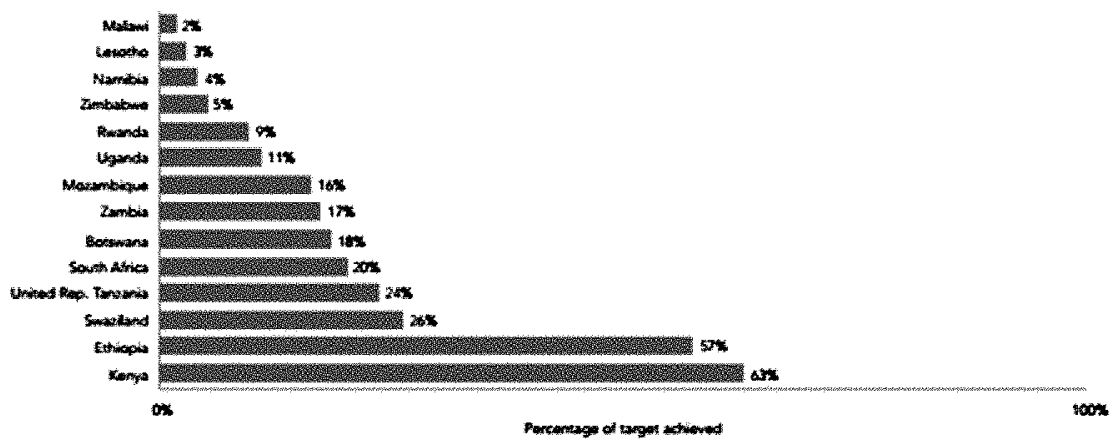

Figure 3. Voluntary medical male circumcision: countries' progress towards 2015 targets, by December 2012.

from future HIV testing, prenatal care, and even from general medical care. Some jurisdictions mandate screening of newborns if the mother does not agree to HIV testing. Studies have shown that healthcare providers in high-income countries are likely to place the interest of the fetus above those of the woman when dealing with women from minority or low-income places. ${ }^{32}$ Although society may recognize and hold a pregnant mother to a moral obligation to act in the best interests of her unborn child, this obligation does not necessarily translate into a legal obligation. ${ }^{33}$ However, it is becoming evident that the

32 Ibid.

33 The CDC recommends routine opt-out HIV screening for all pregnant women as a part of antenatal care and for newborns if the mother's HIV status is unknown. Ibid. at p. 8. 
prevention of mother-to-child transmission of HIV is another means of curbing HIV prevalence, especially in children. An example of a country where there has been such reductions is Ethiopia, which has made gains in increasing access to HIV prevention and treatment services among pregnant women with HIV and children between 2009 and 2012, reducing such transmissions by 50 percent. ${ }^{34}$ The number of women newly infected with HIV declined by 44 percent from 2009 to 2012 in Ghana, by 23 percent in Uganda, and by 21 percent in South Africa. ${ }^{35}$ To spur on an accelerated HIV treatment scale-up, Malawi has begun systematically offering lifelong antiretroviral therapy (ART) to pregnant women living with HIV (Option B+), leading to a 7.5-fold increase in the number of women receiving therapy over a 15-month period in 2011-12. ${ }^{36}$ In 2013, WHO issued new consolidated guidelines for the use of antiretroviral medicines for HIV treatment and prevention, recommending initiation of lifelong antiretroviral therapy for all pregnant and breastfeeding women living with HIV, regardless of their CD4 count. ${ }^{37}$ In fact, Malawi, after convening a stakeholder symposium in 2010 to examine a feasible option from the then new WHO recommendations, decided to put all pregnant or breastfeeding women on ART for life, irrespective of clinical stage or CD4 cell count (Option B+). This has been implemented in Malawi since 2011, and in 2012 the WHO acknowledged the potential advantages and the need to take into account the new Option $\mathrm{B}+$ approach within the public health perspective in resource-limited settings. ${ }^{38}$ Consequently, the WHO, in collaboration with the Malawi Ministry of Health, documented the Malawi experience in implementing Option $\mathrm{B}+$ to adequately advise other countries concerning Option B+'s implementation and potential challenges. ${ }^{39}$

Some countries have used the legislative process to reduce MTCT; for example, the Constitutional Court of South Africa required the government to provide a:

34 See UNAIDS, 2013 Progress Report on the Global Plan: Towards the Elimination of New HIV Infection Among children by 2015 and Keeping Our Mothers Alive, pp. 20-1, available at http://www.unaids.org/sites/default/files/media_asset/20130625_progress_global_plan_en_0.pdf.

35 UNAIDS, supra, note 2, at p. 46.

36 The advice on PMTCT and ART in adults, adolescents, and children was released by the WHO in December 2009 and recommended two prophylaxis options for women not eligible for treatment. Option A expanded on the previously recommended 2006 guidelines approach to PMTCT prophylaxis and included maternal AZT from 14 weeks of pregnancy, a single-dose nevirapine plus AZT/3TC during labor, and then a week of AZT/3TC postpartum with nevirapine syrup for the newborn from birth until cessation of breastfeeding. On the other hand, Option B introduced the use of triple ARVs to the mother from 14 weeks of pregnancy through labor, delivery, and until the end of breastfeeding. See, generally, WHO Regional Office for Africa, Implementation of Option B+for Prevention of Mother-to-Child Transmission of HIV: The Malawi Experience (Report) (2014).

37 UNAIDS, supra, note 2, at p. 46. In ten priority countries in 2012 , fewer than half of pregnant women who were living with HIV and with CD4 counts equal to or lower than 350 cells per microlitre (the threshold for HIV treatment initiation under the earlier 2010 World antiretroviral treatment guidelines) received antiretroviral therapy. Ibid.

38 WHO Regional Office for Africa, supra, note 36.

$39 \mathrm{Ibid}$. The adoption and implementation of Option B+ in Malawi took place over a period of two years from consultation in July 2009 to actual implementation in July 2011. The key steps included: National Consultation and Decision-making, merging of ART and PMTCT Technical Working Groups, formulation of ART/PMTCT guidelines, review of the procurement and supply system, and capacity building of service providers. 
comprehensive and co-ordinated program to realize progressively the rights of pregnant women and their newborn children to have access to health services to combat mother-to-child transmission of HIV $\ldots$ and must include reasonable measures for counseling and testing pregnant women for HIV, counseling HIV-positive pregnant women on the options open to them to reduce the risk of mother-to-child transmission of HIV, and making appropriate treatment available to them for such purposes. ${ }^{40}$

\section{Gender-Based Violence and HIV}

Gender-based violence directly promotes the spread of HIV/AIDS by limiting women's ability to negotiate sexual practices, disclose HIV status, and access medical services and counseling due to fear of gender based violence. ${ }^{41}$

Gender-based violence (GBV) exerts a destructive and disproportionate impact on women and girls, especially in high-prevalence countries in Africa. ${ }^{42}$ GBV may keep women and girls from getting tested for HIV, disclosing their HIV status, and seeking care and treatment. A 2005 study found that about 60 percent of HIV positive women chose not to receive treatment at a Zambian clinic because they were afraid of violent behavior and abandonment by their family. ${ }^{43}$ In the same vein, fear of violence may prevent women and girls from negotiating condom use. ${ }^{44}$ Research studies from India, Kenya, Rwanda, South Africa, Tanzania, the United Kingdom, the United States, and Vietnam demonstrate that women who are HIV-positive are more at risk of violence than women who are HIV-negative, and that violence is a major contributing factor to HIV infection. ${ }^{45}$

40 Minister of Health v. Treatment Action Campaign (2002) CCT 8/02, 2002 (5) SA 721 (CC) para. 135, available at http://www.saflii.org/za/cases/ZACC/2002/15.pdf.

41 Janet Fleischman, Gender-Based Violence and HIV: Emerging Lessons from the PEPFAR Initiative in Tanzania, at p. 5 (quoting Ambassador Eric Goosby, US Global Aids Coordinator) (July 2012), available at http://csis.org/files/publication/120709_Fleischman_ GenderBasedViolence_Web.pdf.

$42 \mathrm{Ibid}$. at p. 1 . GBV is violence that is directed at an individual based on his or her biological sex or gender identity. This would include physical, sexual, and psychological abuse, and threats, coercion, deprivation of liberty and economic deprivation. See Alia Khan, GenderBased Volence and HIV: A Program Guide for Integrating Gender-Based Violence Prevention and Response in PEPFAR Program (October 2011), available at http:/www.salamandertrust.net resources/AIDSTAR-One_GBV_Guidance.pdf.

43 UNIFEM, Facts and Figures: Ending Violence against Women, available at http://www. unwomen.org/en/what-we-do/ending-violence-against-women/facts-and-figures. Likewise in a study on sexual violence and HIV in South Africa, 16 percent of males and 14 percent of females in the 15-19 year-old group would not share a positive diagnosis with their family. See Neil Andersson et al., 'National Cross Sectional Study of Views on Sexual Violence and Risk of HIV Infection and AIDS among South African School Pupils,' 329 (7472) British Medical Journal (2004): 1-55.

44 Ibid.

45 Program on International Health and Human Rights and Harvard School of Public Health, Gender Based Violence and HIV Final DRAFT Report (2009) (submitted to the UN Population Fund for review and discussion). 
Social and cultural norms tend to make changes difficult. The acceptance of masculine norms condoning men's use of power over women promotes power inequality between the genders, which can and does invariably lead to violence. Due to cultural norms, women readily accept and support male dominance; for example, in the South African and Sexual Violence Study it was observed that, among 15-19 year olds, 28 percent of males and 27 percent of females believed that a girl did not have the right to refuse sex with her boyfriend; 55 percent of males and 54 percent of females thought that sexual violence does not include forcing sex with someone you know. ${ }^{46}$ This power bias is even more unequal due to age differences in relationships. It is not unusual for African women to marry at a young age, or to have older intimate partners who are sexually more experienced and active. Consequently, these older men are more likely to have been exposed to HIV/AIDS, and are more likely to infect their younger female partners, especially given that these women believe they are not in a position to negotiate safe sex as a result of unequal power in the relationship. ${ }^{47}$ In Lesotho, about 37 percent of married women believed that a man was justified in beating his wife if the wife argued with him, while 23 percent acknowledged that a beating was justified if a wife refused to have sex with her husband. ${ }^{48}$ In fact, in some African cultures, violence against women is acceptable as a sign of love. How has dealing with violence against women helped in curbing HIV prevalence and contributed to the supposed decline? Although addressing violence against women in the fight against HIV/AIDS should invariably include traditional methods such as antiretroviral drugs, condom use, and treatment, it is even more vital that underlying social issues be addressed in a meaningful manner, in conjunction with public policy. A good example of a successful program is the Stepping Stones Training Program in Tanzania. It offers a model and lasting measurable change in gender-related attitudes and behaviors. ${ }^{49}$ Stepping Stones is a communications, relationships and life skills training package, which also covers HIV prevention and sexual and reproductive health. Stepping Stones is an effective community-based approach to HIV prevention that can improve relationships between men and women, promote gender equality, and create an enabling environment for sexual and reproductive well-being. ${ }^{50}$ Groups come together and present the kind of changes they would like to see. The potential for long-term change rests in intergenerational dialogue, which uncovers and challenges social norms. ${ }^{51}$

46 C. A. Anderson et al., 'The Influence of Media Violence on Youth,' 4 (3) Psychological Science in the Public Interest (2003): 81-110, available at http://www.columbia.edu/ lbh3/ anderson_berkowitz_06.pdf.

47 See Katu Fustos, Gender Based Violence Increase Risk of HIV/AIDS for Women in Sub-Saharan Africa (Population Reference Bureau, 2011), available at http://www.prb.org/Publications/ Articles/2011/gender-based-violence-hiv.aspx.

48 Ibid.

49 Ibid.

50 Gill Gordon and Alice Welbourn, 'Stepping Stones,' Life Skills and Sexual WellBeing: A Desk-Based Review (UNICEF, 2001), available at http://www.unicef.org/lifeskills/ files/ReviewSteppingStones2001.doc.

51 Fustos, supra, note 47. 
Opportunities for integration of GBV programs into HIV responses have been instrumental in creating effective programming in Africa. Some major structural issues that have been considered or are being considered include: ${ }^{52}$

- gender inequalities based on the patriarchal system's understanding of cultural, social, and religious norms and accepted views of masculinity and femininity;

- a legal and policy environment in which laws and policies are implemented and address GBV at the community level;

- a consideration of poverty and socio-economic structures and systems;

- the education system - requires advocacy and engagement between ministries of education and teacher associations;

- integration interventions that promote gender equality and HIV training with women;

- moving forward: what needs to be done-translate the evidence into practice and develop new models, invest in further research, monitor and evaluate models, identify and act on policy operations, share information, invest in capacity building and build partnerships.

\section{The Role of Antiretroviral Drugs and HIV}

Antiretroviral therapy not only prevents AIDs-related illness and death, it also has the potential to significantly reduce the risk of HIV transmission and the spread of tuberculosis..$^{53}$ From 1992 to 2012, antiretroviral therapy averted 6.3 million AIDs-related deaths worldwide, including 5.2 million deaths in low- and middle-income countries. The goal has been to provide antiretroviral therapy to 15 million people by 2015 . In $2012,9.7$ million middle-income countries received antiretroviral therapy, representing 61 percent of all who were eligible under the 2010 World Health Organization initiative. ${ }^{54}$ The new 2010 WHO HIV treatment guidelines for adults and adolescents recommend starting HIV treatment at a CD4 count of 350 cells $/ \mathrm{mm}$ to reduce HIV-related mortality and prevent infections such as tuberculosis. ${ }^{55}$ The successes are directly linked to the drastic fall in the prices of these ART drugs, possibly through the affordable quality of generic medicines, the increase in donor funding, investment in health systems, and the

52 See WHO, Strengthening Gender-Based Violence and HIV Response in Sub-Saharan Africa (Report) (July 2012), available at http:/www.svri.org/GBVHIVWorkshop2012.pdf.

53 UNAIDS, supra, note 2.

54 Ibid.

55 See WHO, Antiretroviral Therapy for HIV Infection in Adults and Adolescents (2010). In July 2010, UNAIDS and WHO launched the treatment 2.0 platform, which aimed at accelerating access to more effective and less toxic drug combinations and diagnostics, and to start antiretroviral therapy earlier. See UNAIDS, Policy Brief Using TRIPS Flexibilities to Improve Access to HIV Treatment (Policy Brief 2010), available at http:/www.unaids.org/sites/ default/files/media_asset/JC2049_PolicyBrief_TRIPS_en_1.pdf. 
use of flexibilities in intellectual property laws. ${ }^{56}$ The demand for treatment far exceeded the targets reached, and as a result the UN General Assembly high-level meeting in June 2011 was compelled to adopt some ambitious targets, including the elimination of new HIV infections among children, and increasing the number of people on life-saving treatment to 15 million, as well as reducing tuberculosis and related deaths in people with HIV by half in five years. ${ }^{57}$ The success of the roll out of the first batch of ART was largely the ability of the generic manufacturers to supply cheap antiretroviral drugs. In the past decade, the annual price of first-line antiretroviral drugs reduced tremendously from over US\$10,000 per person in 2000 to less than US\$116 for the cheapest in the first quarter of 2010 (a 99 percent reduction). ${ }^{58}$ The second and third line of ART medicines were determined by the impact of patent protection. ${ }^{59}$ Consequently, developing countries could avail themselves of the flexibilities under the intellectual property rules so as to avoid or lesson the negative effect of the expected high monopoly prices attached to new medicines. ${ }^{60}$

Many African countries have incorporated intellectual property protections in their domestic laws, including the granting of patent protection on medicines. A majority of African countries, 42 of the 53, are also members of the WTO, and are therefore required to adhere to its rules, particularly regarding patent protection to pharmaceuticals. ${ }^{61}$ These countries can use the waiver to import essential medicines cheaply without the requirement of stringent patent protection. ${ }^{62}$ The Doha agreement clearly provides that the TRIPS agreement 'does not and should not prevent members from taking measures to protect public health and this could be interpreted and implemented in a manner supportive of WTO members' right to protect public health and in particular to promote access to medicines for all. ${ }^{63}$ In 2002, developing countries were concerned that developed countries

56 WHO, Intellectual Property Rights and Access to Medicines (2012), available at http://apps.who.int/medicinedocs/documents/s17521en/s17521en.pdf.

57 Ibid.

58 See WHO, Transaction Prices for Antiretroviral Medicines and HIV Diagnostics from 2008 to March 2010 (Report) (May 2010), available at http://www.who.int/hiv/pub/amds/ GPRMsummary_report_may2010.pdf.

59 The average price for the second-line regimens is apparently still high in both low- and middleincome countries. Ibid. With the advent of the World Trade Organization and the adoption of the Trade-Related Aspects of Intellectual Property Rights (TRIPS) agreement, member countries are required to harmonize their patent legislation and to submit to stringent regulations for the protection of patents on, among other things, medicinal and medical devices. Ibid.

$60 \mathrm{Ibid}$. This was reaffirmed in the Political Declaration on HIV/AIDS, highlighting the flexibilities of the TRIPS Agreement to improve access to treatment. See Political Declaration on HIV/AIDS, G.A. Res. 60/262, Doc A/Res. 20. 60/262 (2006), available at http://data.unaids.org/ pub/Report/2006/20060615_HLM_PoliticalDeclaration_ARES60262_en.pdf,

encouraging governments to 'consider, whenever necessary, adapting legislation in order to use the full flexibilities contained in the TRIPS, including those recognised in the Doha Declarations on the TRIPS Agreement and public health and the WTO decision of 30 August 2003).

61 Ibid.

62 Ibid.

63 WHO, Declaration on TRIPS Agreement and Public Health (2001), WT/MIN(01)/ DEC/2, 4 (2001), available at http://www.wto.org/english/thewto_e/minist_e/min01_e/mindecl_ trips_e.htm. 
were insisting on an overly narrow reading of TRIPS, and therefore consequently started the round of talks that resulted in the Doha Declaration. Hence, the Doha Declaration is a WTO statement that clarifies the scope of TRIPS, indicating that TRIPS can and should be interpreted in light of the goal 'to promote access to medicines for all. ${ }^{64}$

\section{THE AGREEMENT ON TRADE RELATED ASPECTS OF INTELLECTUAL PROPERTY RIGHTS (TRIPS)}

\section{A. WTO and TRIPS Agreement in Relation to HIV/AIDS}

In 1995 when the WTO was created, the TRIPS Agreement-building on existing multilateral treaties as administered by the World Intellectual Property Organization (WIPO) - introduced minimum standards for protecting and enforcing intellectual property rights, including a new monitoring and dispute settlement mechanism. Under Article 27.1 of the TRIPS Agreement, WTO members are required to make patents 'available for any inventions, whether products or processes, in all fields of technology,' which includes patents for pharmaceutical processes and products. ${ }^{65}$ The required minimum term of protection a country must make available under the TRIPS is 20 years from date of filing. However, at the Uruguay Round, which was the eighth round of multilateral trade negotiations, countries had the discretion to determine the duration of patents, consequently, about fifty countries did not grant patent protection for pharmaceutical products while others also excluded pharmaceutical processes. ${ }^{66}$ In 1994, when TRIPS was introduced, it reduced the discretionary power of WTO members to tailor key aspects of their intellectual property rules. ${ }^{67}$ So, although the TRIPS Agreement marked a new beginning of obligations regarding the protection and enforcement of intellectual property, WTO members still maintain significant policy options, flexibilities, and safeguards, including the liberty to determine the grounds for issuing compulsory licenses ${ }^{68}$ Compulsory licenses are mechanisms used by public authorities to authorize the use of a patent protected by the government or third party without the consent of the patent holder. This may be issued on various grounds of general interest, such as public health. Some examples of African countries that have availed themselves in their laws to issues compulsory licenses for medicines include:

- Zimbabwe, in 2002 published a declaration of a state of emergency for HIV/AIDS for six months (with further extensions) thereby empowering the government or authorized persons to "make or use

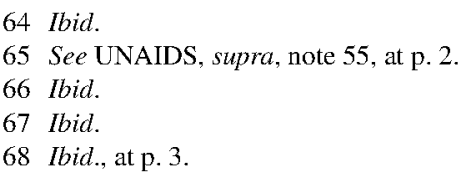


any patented drug, including any antiretroviral drug' and 'to import any generic drug used in the treatment ... of HIV/AIDS. ${ }^{\prime 69}$

- Likewise, in 2004 in Mozambique, a compulsory license was issued to the Pharco Company to supply a triple compound of lamivudine, stavudine and nevirapine with a royalty rate not exceeding 2 percent. $^{70}$

Other related issues deal with the following:

- Parallel imports. Companies often charge lower prices for a medicine in one country than in another, taking a range of market factors into account. This invariably means that a country with limited resources may be able to afford more of a patented medicine by buying it abroad at a lower price and importing it, instead of buying it directly in its domestic markets at the higher price.

- Bolar provision/regular exception. The application of general exceptions, such as early regulatory approval of generic pharmaceutical products would allow the use of a patented invention without authorization from the patent owner in order to obtain marketing approval of a generic product before the patent expires. This facilitates access to cheaper medicine.

- Exception for least developed countries. Use is made of transition periods for developing countries and a longer, extendible transition period for least developed countries. For example, with reference to pharmaceutical products, paragraph 7 of the Doha Declaration as implemented by the TRIPS Council decision of June 2002, exempts least developed countries from having to grant patents and from providing for the protection of undisclosed information until January 2016. These transition periods are subject to further extension under Article 66.1 of the TRIPS Agreement. ${ }^{71}$

The importance of the Doha Declaration cannot be overstated, but it did leave out one unresolved issue under Article 31(f) of TRIPS, which requires that countries issuing licenses for the local manufacture of antiretroviral drugs do so only if the antiretroviral drugs are to be used mostly in the domestic markets. Accordingly, this restriction is likely to limit the production of antiretroviral drugs under compulsory licenses for export. ${ }^{72}$ In the same vein, it means that countries with inadequate manufacturing capacity could not actually use compulsory licensing

69 See Government of Zimbabwe, Declaration of Period of Emergency: HIV/AIDS Notice 2002, General Notice 240 of 2002, available at http://www.cptech.org/ip/health/c/zimbabwe/ zim05242002.html (accessed 17 May 2012).

70 See Government of Mozambique, Compulsory License No 01/MIC/04, available at http://www.cptech.org/ip/health/c/mozambique/moz-cl-en.pdf. The Zambian government also issued a similar license for Pharco for the same combination at a royalty not exceeding 2.5 percent.

71 Ibid.

72 Ibid. 
as a source of affordable medicines. ${ }^{73}$ The 30 August 2003 WTO General Council Decision resolved this issue, as it allows WTO members to grant compulsory licenses for the production and export of generic medicines to developing countries and least developed countries with insufficient or no manufacturing capacity in the pharmaceutical arena. This is referred to as the 'Paragraph 6 solution,' and was formalized as an amendment to the TRIPS agreement in $2005 .{ }^{74}$ Rwanda is a good example of a country that used the ' 30 August 2003' mechanism to its advantage. ${ }^{75}$

The use of these options and flexibilities can directly and indirectly help to increase the supply and accessibility of necessary medicines, thereby allowing countries to attain a balance between intellectual property protection and development priorities, including public health objectives. ${ }^{76}$ However, many countries, including African countries, have yet to amend their laws to optimally incorporate the flexibilities, which is a precondition for their use. ${ }^{77}$

\section{B. The Role of Regional Agreements in Intellectual Property Protection in Africa}

It is not common to find local patent offices in African countries with the capability to examine patent applications. Only Algeria, Egypt, Ethiopia, Kenya, Morocco, Mozambique, and Zambia have such local offices. ${ }^{78}$ Many African countries rely on patent examiners at the African Regional Intellectual Property Organization (ARIPO) to determine whether a patent meets the patentability requirements.

\section{The African Regional Intellectual Property Organization}

ARIPO, formerly the African Regional Industrial Property Organization, ${ }^{79}$ is an intergovernmental organization for the cooperation among African states in patent and other intellectual property matters. ARIPO was established by the Lusaka Agreement of $1976 .^{80}$ It has the capacity to hear applications for patents and

73 Ibid., at p. 4.

74 Ibid.

75 In 2007, Rwanda was the first country to announce its intention to use the August 2003 WTO decision to import a generic fixed-dose combination of zidovudine, lamivudine, and nevirapine from a Canadian generic manufacturing company. The compulsory license granted under the Canadian Access to Medicines Regimes authorised the delivery of enough of the fixed dose combination for one year of treatment of about 2,100 people living with HIV at the most affordable price globally. Ibid., at p. 6.

76 Ibid.

77 It is important to note that a number of countries are parties to bilateral or regional free trade agreements containing 'TRIPS plus' provisions - that is, the level of intellectual property protections that go beyond the minimum standards required by the TRIPs agreement. Ibid., at p. 8 .

78 See WHO, supra, note 56.

79 The name of the organization changed from 'African Regional Industrial Property Organization' to 'African Regional Intellectual Property Organization' in 2005.

80 The objectives of the Organization, as enshrined in Article III of the Lusaka Agreement, is the cooperation in industrial property intended to achieve technological advancement for economic 
registered trademarks in its member states that are parties to the Harare (patents) and Banjul (marks) protocols known as the 'Harare Protocol,' signed in Zimbabwe in $1982 .{ }^{81}$ Therefore, the Protocol empowers the ARIPO Office to grant patents and register industrial designs, marks, and utility models. ARIPO's 18 member states are mostly English-speaking countries. Rwanda became the eighteenth member state on 24 March 2010. These member states rely on the organization to determine whether a patent application meets the requirements for patentability. Each member state has a six-month period from the granting of the patent by an ARIPO examiner to accept or reject the application of the patent within its territory. ${ }^{82}$

\section{The Bangui Agreement and the African Intellectual Property Organization}

The African Intellectual Property Organization (OAPI) was established in 1962 as an international law instrument governing intellectual property matters for its member states. The Bangui Agreement was revised in 1999, and even though the TRIPS Agreement was already effective, it failed to incorporate the public health flexibilities in the TRIPS Agreement, such as stricter patentability criteria, compulsory licenses, exceptions, exemptions, etc. ${ }^{83}$ Similarly, the Bangui Agreement does not consider the level of development of its member states, and in particular the waiver of the obligations of less developed countries (LDCs) under the TRIPS Agreement from providing patents to pharmaceuticals until $2016 .{ }^{84}$ Unlike ARIPO, which provides member states with the option to accept or reject a pharmaceutical patent decision, once a patent is granted by the OAPI secretariat, it automatically becomes binding on all member states. ${ }^{85}$ There is a need to reform the Bangui Agreement to allow OAPI member states who are also members of the WTO to incorporate the TRIPS Agreement flexibilities into their national laws. ${ }^{86}$

\section{SOME POSITIVE STORIES}

\section{A. A Success Story - The Case of Uganda}

Uganda is one of the few African countries with a drop in HIV infection rates. A combination of factors account for this success, but the government policy adopted impacted greatly on adult prevalence. It fell 15 percent in the early 1990 s,

and industrial development of the member states. See African Regional Intellectual Property Organization (ARIPO), available at http://www.aripo.org/about-aripo.

81 See Part B.5.b.2 (discussing on the Bangui Agreement and OAPI).

82 Ibid.

83 See WHO, supra, note 56.

84 See supra, Part B.5.a.

85 Ibid.

86 In 2009, the United Nations Development Program (UNDP), in conjunction with the Association for the Promotion of Intellectual Property in Africa (APPIA), the Regional Office for Central Africa of the WHO, and other non-governmental organizations, called for a regional consultation on the issue to reform the Bangui Agreement. Ibid. 
to about 5 percent in 2001, and then an estimated 6.7 percent by the end of $2005 .^{87}$ According to an AVERT article on HIV/AIDS in Uganda, ${ }^{88}$ a series of significant events occurred between the diagnosis of the first AIDS case in Uganda in 1982 and the early 2000s, which contributed to a reduction in prevalence by 2005 . These events include, but are not limited to President Yoweri Museveni's swift response in 1986 to the emerging crisis, where he embarked on a nationwide tour to talk about the disease, asserting to the general public that avoiding AIDS was a patriotic duty, encouraging them to abstain from sex before marriage, to be faithful to their partners, and advocating the use of condoms. A 1988 national survey found the average prevalence in the population to be 9 percent. Subsequently, an AIDS Information Center was opened in 1990 to provide voluntary counseling and testing. By 1992, the government had adopted a multi-sectorial approach to addressing the epidemic. In the same vein, in 1994, various governmental departments established individual AIDS control program units. The government used loans from the World Bank and additional help from donors to set up the Sexually Transmitted Infections Project. By 1995, Uganda was seeing a decline in HIV prevalence. In 1998, the Drug Access Initiative was established to lobby for reduced prices on ARV medications. In addition, an infrastructure was established to make these drugs accessible to the populace. By 1999, the Ugandan Ministry of Health started a voluntary door-to-door HIV testing program, and in 2000 the government began to mainstream Uganda's poverty eradication Action Plan. In 2001, the World Bank agreed to provide assistance over the next five years by spending 4.7 million dollars on Uganda's AIDS prevention and treatment programs. By this time, the HIV prevalence rate was reported to have dropped to about 5 percent. But by 2005, the rate had risen slightly, which has been partially attributed by some to the United States' policy in encouraging a shift in Uganda's HIV prevention policy towards abstinence only.

Uganda represents a fairly unique case in that other Sub-Saharan African countries also experienced a rapid increase in HIV incidence at the same time as Uganda, yet none has been as successful in reducing the rates of prevalence. ${ }^{89}$

Regardless of whether the rate of decline has been inflated or the difference is smaller than we have been led to believe, I believe Uganda's approach should be emulated by other African countries: Uganda's government demonstrates political leadership in mobilizing its population in the fight against HIV. African governments must be committed to the cause and actively involve their populations in the fight. ${ }^{90}$ The general approach to combat HIV has been referred to as the $\mathrm{ABC}$ approach, standing for: $\mathrm{A}=$ encourage sexual Abstinence until marriage; $\mathrm{B}=$ advise those who are sexually active to Be Faithful to a single

87 AVERT.org, HIV \& AIDS in Uganda, available at http://www.avert.org/aidsuganda.htm (accessed 26 September 2012) (hereinafter HIV/AIDS in Uganda). This is not to say that Uganda is out of the woods; HIV prevalence in Uganda is still high but much lower than it once was.

88 Ibid.

89 The authenticity of Uganda's official statistics has, however, been challenged as being artificially deflated. See ibid., at p. 14.

90 In 2004, for example, 12 members of parliament made public their decision to undergo HIV testing, sending a message to the population that it is a positive thing to know one's status. 
partner; and $\mathrm{C}=$ if you have more than one sexual partner, always use a Condom. $A n A B C$ approach focuses on what individuals can do to change (or maintain) behavior, and thereby avoid or reduce risk of infection, while also recognizing that not all individuals have control over their sexual behavior. An ABC plus approach incorporates broader goals such as advancing women, increasing access to education, and decreasing poverty. ${ }^{91}$ This strategy was taken seriously in Uganda, and proved effective in arresting the spread of the virus in conjunction with a number of other factors: ${ }^{92}$

- Communication. This is vital-what is said and how it is said can impact people's behavior. The message about HIV/AIDS was communicated to a diverse population by the government by word of mouth, beginning at the grassroots level. The stigma associated with HIV/AIDS was undermined by frank and honest discussion about sex. The message was couched in simple and understandable language. For example, 'Zero Grazing' (which embodied the $\mathrm{ABC}$ approach discussed above) was a term used to promote the avoidance of casual sex.

- Community action. An early action of the government in the 1980 s was its recruitment of its citizens to participate in the fight against the epidemic by forming TASO, an AIDS support organization which provides all kinds of support to people with HIV and their families. ${ }^{93}$

- Fear. People are more likely to avoid risky behavior if they know people who have died of AIDS or its related illness. Fear was also used as a tool in curtailing such behavior, given that most people

91 Christian Connections for International Health, The ABC Approach to Preventing the Sexual Transmission of HIV: Common Questions and Answers, 4 February 2007 (hereinafter 'The ABC Approach'), available at http://www.newparadigmfund.org/research/Green\&Herling_ABC_ Approach_Feb07 percent282 percent29.pdf.

92 See AVERT.org, supra, note 87. The issue of condom usage has been somewhat controversial. Some faith-based organizations certainly would love to see sexual abstinence made the central pillar of the fight against HIV, hence some Ugandan teachers report that they are expected not to discuss condoms in schools, but rather to emphasise the policy of abstinence only. The condom shortage in Uganda in 2004 as a result of a nationwide recall of free condoms distributed in clinics (supposedly because of their poor quality) made the availability of condoms not only scarce and expensive, but also suspicious.

93 The AIDS Support Organization (TASO) was founded in 1987 by Dr Noerine Kaleeba and 15 other colleagues, most of whom have now passed away due to AIDS. The founding of TASO was based on people who were unified by common experiences faced when encountering HIV/AIDS at a time of high stigma, ignorance, and discrimination.

Consequently, the founders met informally in each other's homes or offices to provide mutual psychological and social support. Cohesion among these individuals was strengthened by the fact that they were either directly infected with HIV, or they were implicitly affected because their very close familial associates were infected. See the AIDS Support Organization, http://www.tasouganda.org/ (accessed 27 September 2013).

The year 2005 was the third year under the TASO five-year life strategic plan (2003-7). During that year, a number of achievements and other events were realised. For some of the major highlights of that year, see Taso Uganda Limited, Annual Report (2005), available at http://www.stratshope.org/images/resources_files/Bk17_ws.pdf. 
knew at least one person infected with HIV (a 1995 University of Cambridge study showed that 91.5 percent of Ugandan men and 86.4 percent of women knew someone who was HIV positive). ${ }^{94}$

- Antiretroviral treatment. The value of ARV drugs in Africa cannot be emphasized enough. Not only may they help prolong the lives of those with HIV but they also provide added incentives for people to be tested. Once tested, if found HIV-negative, they can avoid risky behavior; however, if found HIV-positive, then they have the possibility of seeking treatment. Without this hope for treatment, people are unlikely to voluntarily get tested. Uganda, in 1998, was the first country in Africa to run test programs for the purpose of better understanding how an ARV program could be set up and run in a developing country with limited resources.

ARVs were made accessible in many Sub-Saharan countries at reduced prices, but were still expensive and unaffordable to most patients. It is only recently that a few of these countries, with the help of the World Bank, the Global Fund Grant, and other initiatives are beginning to provide their patients with free drugs. Uganda began to offer this medication for free in 2004. No doubt today, Uganda stands out as one those countries with the greatest progress in curbing the spread of HIV/AIDs.

\section{B. A Success Story: The Case of Nigeria}

Nigeria has the second largest population of people living with HIV, but only onethird of those eligible individuals are receiving treatment and only 18 percent of HIV-positive pregnant women are receiving antiretroviral medications to prevent mother-to-child transmission - Nigeria therefore has had to become innovative. To implement the commitments in the 2011 UN Political Declaration on HIV/AIDS and accelerate progress towards universal access to HIV prevention, treatment, care, and support, Nigeria developed the President's Comprehensive Response Plan (PCRP). ${ }^{95}$ The PCRP's aim is to bridge the gap in service provision and funding, thereby offering an investment case for HIV financing. ${ }^{96}$ The investment case assesses needs and gaps, identifies focus areas, and quantifies the degree of scale-up to close gaps, determine financing needs, and analyze expected impacts on lives saved, new infections averted, and costs saved. ${ }^{97}$ The PCRP has set target coverage levels for priority intervention, such as a 140 percent increase in HIV prevention efforts in key populations and a 400 percent increase in the provision of antiretroviral therapy to pregnant women. The country projects that the implementation of the PCRP would save 46,000 and avert a 105,000 new

94 AVERT.org, supra, note 87.

95 UNAIDS, supra, note 2, at p. 76.

96 Ibid.

97 Ibid. 
infections by $2015 .{ }^{98}$ Total cost savings are projected at US $\$ 1.65$ billion through delayed or averted HIV treatment costs. To successfully implement the plan, the PCRP calls for domestic investment to rise by 73 percent, which invariably would increase the proportion of overall domestic spending on HIV from 25 percent to 45 percent between 2014 and $2015 .{ }^{99}$ In the same vein - and in keeping with the 2012 visionary step of the African Union (AU), articulating a roadmap for shared responsibility and global solidarity for AIDS, tuberculosis, and malaria response in Africa-several African countries have explored a number of strategies to generate new domestic funding for HIV response. ${ }^{100}$ Countries like Ethiopia, Malawi, and Namibia are 'mainstreaming' HIV, requiring different government entities to allocate at least 2 percent of their budgets to HIV activities. ${ }^{101}$ Some countries - Kenya, the United Republic of Tanzania, and Zambia - are considering the possibility of establishing trust funds. In the past twelve years, Zimbabwe has instituted a national HIV/AIDS levy as a component of the national tax system, as well as exploring the possibility of incorporating the private and informal sectors to contribute to this levy. ${ }^{102}$ In fact, Malawi has projected that instituting and allocating to HIV programs 1 percent of an existing 5 percent levy on the operating surplus of telecommunications firms of up to US\$2.4 million would be generated in 2013. Thus African countries are reducing dependency on international HIV funding by thinking in innovative ways.

\section{A Success Story: The Case of South Africa}

To appreciate the HIV/AIDS journey in the history of South Africa, one can correlate HIV prevalence with the political leaders and history of the country. When Mandela left Robin Island over 23 years ago, HIV prevalence was over 4 percent, with life expectancy at 66 years. ${ }^{103}$ President Mandela implemented HIV policies including the 'AIDS Plan,' but due to a failure in leadership and lack of national capacity, these efforts did not pay off. By the late $1990 \mathrm{~s}$, although a progressive policy was developed, it was plagued by almost a decade of political mistakes, controversies, and misinformation resulting in numerous preventable deaths. ${ }^{104}$ These included failure to adequately and properly educate the public about HIV/AIDS, and the refusal to provide infected pregnant mothers with AZT and nevirapine to prevent transmission of HIV onto newborns. ${ }^{105}$ President Mbeki's subsequent public questioning of HIV/AIDS science, and his health minister's promotion of garlic, beetroot, and lemons instead of antiretroviral

100 UNAIDS, supra, note 2, at p. 76.

101 Ibid.

102 Ibid.

103 Peter Navario, 'HIV/AIDS in South Africa: Improved Prognosis,' Global Health (2010), 22 February.

104 Ibid.

105 Ibid. 
drugs, as well as the government's refusal to provide HIV treatment until 2004, all contributed to the high prevalence of HIV/AIDs in South Africa. Although president Zuma's election in 2009 and his administration were welcomed with skepticism, ${ }^{106}$ he has surprisingly raised the bar for the management of HIV/AIDS. He stated on World AIDS Day in December 2009 that it was his intention to get an HIV test and encourage all South Africans to learn about their HIV status. His administration acknowledged the failed policies of previous administrations and advanced new, evidenced-based policies, including those dealing with the start of early treatment for pregnant women, the treatment of patients co-infected with $\mathrm{TB}$, and the treatment of infected children. ${ }^{107}$ In the same vein, his administration increased the HIV/AIDS budget in 2010 to pay for any new patients who would qualify for treatment under the new WHO guidelines. Consequently, beginning in 2010, all HIV-positive children under the age of one would be suitable for treatment, regardless of their CD4 count (a measure of their immune system's strength). ${ }^{108}$ Likewise, pregnant women living with HIV and patients co-infected with TB will now qualify for ARVs if their CD counts falls to 350 or less. Instead of giving pregnant women treatment only in the last trimester, treatment would be given from the fourteenth week of pregnancy, to prevent mother-to-child transmission. ${ }^{109}$ President Zuma's approach is apparently paying off as the scaledup response has been effective in boosting the number of people on ART treatment and reducing the number of children born with HIV between 2009 and 2011 by 40 percent. ${ }^{110}$ President Zuma, I believe, sums this best when he states: 'We have no choice but to deploy every effort, mobilise every resource, and utilise every skill that our nation possesses. ${ }^{111}$

\section{LESSONS LEARNED AND RECOMMENDATIONS}

\section{A. Lessons Learned: The Case of Malawi}

The Malawi experience in reducing HIV transmission through MTCT using the $\mathrm{B}+$ option in such a limited resource setting demonstrates that with improvements on any shortcomings, ${ }^{112}$ other countries may consider and implement this

106 Zuma, who had publicized relations with a young HIV infected woman who subsequently accused him of rape, when reproached about precaution taken to prevent contracting HIV during the encounter with her, naively stated he had showered after the encounter. Zuma fathered his twentieth child out of wedlock. However, Zuma was acquitted of the rape charges and apologized for his shortcomings. Ibid.

107 Ibid.

108 'South Africa: Improvement in HIV Policy at Last;' Plus News Global, available at http://www.irinnews.org/Report/8298/south Africa-Improvements-in-HIV-policy.

109 Ibid.

110 Ibid.

111 Ibid.

112 Challenges included the following:

- There was a lack of appropriate health infrastructure, especially given the increase in clientele once the program was underway. 
approach successfully. Some lessons learned include but are not limited to the following: ${ }^{113}$

- Strong government leadership is important in creating and enabling an environment for the implementation of Option B+.

- Adoption of relevant policies, strategies, and guidelines are essential in the implementation of the program.

- Integration of PMTCT into ART programs is very beneficial.

- Task-shifting with clear guidelines and adequate engagement of all stakeholders enhances the efficiency and the outcomes of the program.

- Although Malawi's experience with PMTCT Option B+ is not perfect, and probably not ideal, it has nonetheless demonstrated that it is possible for a low-resource country to successfully implement Option B+ as an avenue to reduce HIV infections among children and to keep mothers alive. ${ }^{114}$

- There was inadequate linking of maternal and pediatric care resulting in mothers not actually being clear about pediatric follow-up schedules, which in turn limited or impacted the coverage of HIV-exposed children.

- Receiving HIV test results and then beginning pediatric ART was a challenge.

- Because HIV test kits were often out of stock, procurement of medicines and commodities became a challenge.

- Same-day testing, counseling, and initiation of clients accessing PMTC was somewhat problematic as some healthcare workers were not comfortable initiating women on the same day, suggesting that the women were not adequately prepared or needed time to prepare psychologically, given that they had just found out about their HIV status. In the same vein, others may need to discuss the results with their spouses or family before starting treatment. Consequently, it was reported that some women accepted drugs but never took them or simply returned them to the clinic.

- The quality of testing was also an issue, as data from the Ministry of Health showed that out of the women whose HIV status was ascertained, only about 75 percent (in 2009-80 percent in 2011) were correctly identified. In 2012, up to 20 percent of HIV-infected pregnant women received a negative result (false negatives), while roughly 0.4 percent of HIV-negative pregnant women were said to be receiving positive results (false positives). This problem is apparently now resolved by mandatory confirmatory testing prior to initiating ART in all patients.

- Failure to adequately involve male family members like husbands and village heads may also pose a problem.

- Human resource for healthcare is constrained or limited in training that integrates service delivery.

See WHO Regional Office for Africa, supra, note 36, at pp. $23-4$.

113 Ibid., at p. 27.

114 Ibid., at p. 28. 


\section{B. Lessons Learned: The ABC Approach}

Lessons can be drawn from the comments and criticism of the $\mathrm{ABC}$ approach in Uganda. Taking a look at some of these comments is a first step in learning how to address them in other countries.

Some argue that the $\mathrm{ABC}$ approach is overly simplistic and needs to go 'beyond $\mathrm{ABC}$ ' to an approach that includes other interventions such as voluntary counseling and testing (VCT), the treatment of HIV and other STIs, destigmatization, the reduction of poverty, a movement towards political openness, and educating women and improving their status. Of course, these interventions should be promoted forcefully, as they are critical matters of justice and human rights, and they would foster an atmosphere that encourages changes in sexual behavior. ${ }^{115}$ Nevertheless, they do not, in themselves, directly prevent the sexual transmission of HIV, but are effective only to the extent that they lead to increased practice of $\mathrm{A}, \mathrm{B}$, or $\mathrm{C}$ behaviors. ${ }^{116}$ Data show that expanding access to VCT does not necessarily reduce HIV prevalence in a population. ${ }^{117}$ In some countries HIV prevalence has risen - rather than fallen - with income level. ${ }^{118}$ The best way to directly influence the sexual transmission of HIV is through changes in sexual behavior. Incorporating a range of other approaches in an HIV prevention strategy can be helpful if it is designed to lead clearly to changes in sexual behavior. If they are merely promoted, instead of a strong focus on $\mathrm{ABC}$-related sexual behavior changes, they are not likely to be successful. ${ }^{119}$

Critics of the $\mathrm{ABC}$ approach also believe that it demands an unrealistic standard of behavior and make statements such as: 'The behavioral bias of the $\mathrm{ABC}$ approach is based on the assumption that individuals all have an innate and equal power to make perfectly correct decisions about every issue in their sexual and reproductive health lives,' or, '[w]e all know that abstinence and couples being mutually faithful would be great if they were applicable to everybody's lives, but they're not.' ${ }^{120}$ Critics of $\mathrm{ABC}$ argue that the African culture is polygamous, and thus Africans generally tend to have many partners and tend to engage in sex at an early age. According to this logic, A and B behaviors are not realistic, and risk-reduction programs are justified by the alleged reality that Africans have

115 The ABC Approach, supra, note 91, at p. 2.

116 Ibid.

117 P. Glick, Scaling Up HIV Voluntary Counseling and Testing in Africa: What Can Evaluation Studies Tell Us About Potential Prevention Impacts? Strategies and Analysis for Growth and Access ('SAGA'), Cornell University SAGA Working Paper, March 2005; R. Wolitski et al., The Effects of HIV Counseling and Testing on Risk-Related Practices and Help-Seeking Behavior, 9 (3) AIDS Education and Prevention (1997): 52-67.

118 In Uganda, as in some other African countries, HIV prevalence is higher in urban areas than rural, and tends to be higher among the economically advantaged population as measured by wealth or employment status. This tends to reflect that people with higher education are more likely to adopt risky behavior, while the more educated tend to be wealthier as they are likely to be employed and thereby face more opportunities to contract HIV/AIDS. See Elizabeth Lule and Markus Haacker, The Fiscal Dimension of HIV/AIDS in Botswana, South Africa, Swaziland, and Uganda (World Bank Group, 2012), p. 240.

119 The ABC Approach, supra, note 91, at p. 2.

120 The ABC Approach, supra, note 91, at p. 14. 
many sexual partners and that women in particular can do nothing about it. ${ }^{121}$ Consequently, the critics argue that international health organizations should put a majority of their prevention resources into risk reduction measures, primarily condom promotion. ${ }^{122}$

Obviously, many factors can limit or take away a person's ability to practice abstinence, faithfulness, or consistent condom use. These factors include poverty, illiteracy, instability, displacement, and gender disparity. Some of the strongest evidence for an $\mathrm{ABC}$ approach comes from situations in which there were high levels of poverty, illiteracy, and instability. When Uganda began to respond to HIV/AIDS in the late 1980s and early 1990s, it was just emerging from two decades of war and extreme civil unrest. ${ }^{123}$ In spite of this, Ugandans mounted an effective response to HIV/AIDS in spite of the difficult situations in which they were living. Consequently, the $\mathrm{ABC}$ approach is attainable in spite of all the odds, and therefore could be easily implemented in other countries.

Some observers allege that the ABC approach is driven by the ideology of US conservatives and that PEPFAR has inappropriately imposed it on other countries. In fact, the $\mathrm{ABC}$ approach was developed and successfully implemented by Africans without any significant involvement of the United States or other large donor organizations. ${ }^{124}$ Other countries in Africa have since adopted an $\mathrm{ABC}$ approach, but Uganda still provides the best example of a balanced and successful implementation of the approach. ${ }^{125}$ Africans, and particularly Ugandans, should be given the credit for developing an approach that is culturally relevant, low-cost, sustainable, and successful. ${ }^{126}$

Some observers have also suggested that the $\mathrm{AB}$ components are no longer as relevant in an era of antiretroviral treatment (ART). A public statement from the Ugandan government - the lead author being the official who ran Uganda's national AIDS Control program in the earliest years - is that $A B C$ is needed even more in the era of antiretroviral treatment: abstinence, being faithful, and condom use are complementary, synergistic, and inseparable components in a country's HIV/AIDS national prevention and control programs, and should be maintained with extra urgency, even in the era of ART. ${ }^{127}$

Faith communities and leaders have been accused of contributing to the stigma toward people living with AIDS (PLWAs), and some feel that it is inherently stigmatizing when faith leaders promote abstinence and faithfulness from a moral

121 Ibid.

122 Ibid.

123 Ibid.

124 Although Ugandans did not invent the $\mathrm{ABC}$ approach or necessarily use the term 'ABC' at the beginning of the pandemic, Uganda's response was to promote abstinence, faithfulness, and, later, condom use. Ibid.

125 The ABC Approach, supra, note 91.

126 The success of this indigenous approach demonstrates that we should not always assume that all the solutions to the problems of the poor lie outside their communities and populations. Ibid., at p. 23.

127 S. Okware et al., 'Revisiting the ABC Strategy: HIV Prevention in the Era of Antiretroviral Therapy,' 81 Postgraduate Med. J. (2005): 625-8, available at http://pmj.bmjjournals.com/cgi/ reprint/81/960/625. 
point of view. ${ }^{128}$ Although this may be true in some instances, in many situations, faith communities have effectively addressed stigma by encouraging compassion and effectively promoting A and B behaviors. Uganda and Senegal stand out as African countries with relatively little AIDS-associated stigma. ${ }^{129}$ Both countries promoted A and B behaviors, and partnered with Christian and Muslim faithbased organizations (FBOs) in important ways. Rather than being seen as part of the problem, faith communities should be made part of the solution, and their support should be enlisted at a national level..$^{130}$

In the same vein, politicians have criticised condom promotion as 'pushing young people into sex,' and have described pre-marital sex as deviant and immoral. ${ }^{131}$

Uganda provides evidence that far from being insensitive to the needs and status of women, an $\mathrm{ABC}$ approach can go hand in hand with raising the status of women and the social responsibility of men. Under Uganda's ABC approach, women were empowered to leave husbands and boyfriends who were unfaithful and who were putting them at risk of infection. ${ }^{132}$ More women have become economically independent, and more women and girls have gone further in their education. Uganda also targeted men and boys with abstinence and 'zero grazing' messages. ${ }^{133}$ Reaching men with $\mathrm{AB}$ messages is crucial to achieving behavior change, given the prevailing power disparities between the genders.

\section{CONCLUSION}

There is no doubt that some progress has been made by international and national investment in dealing with HIV/AIDS since its inception in the world, and in particular in Sub-Saharan Africa where the rate of new infections in 2012 slowly declined - the number of new infections being approximately 25 percent lower than during the peak of the epidemic in 1995. ${ }^{134}$ Although in 2012 an estimated 1.4 million AIDS-related deaths occurred in the region, this number represents an 18 percent decline in annual HIV-related mortality in the region since 2004. ${ }^{135}$ In fact, even the adult (aged 15-49) HIV prevalence is said to have declined from 5.8 percent in 2001 to 5.2 percent in $2012 .{ }^{136}$ In spite of this encouraging data, putting it in the total context of the epidemic, Sub-Saharan Africa still remains the region most heavily affected by the epidemic, accounting for 67 percent of HIV infections worldwide, 68 percent of new infections among adults,

128 The ABC Approach, supra, note 91.

129 Ibid.

130 Ibid.

131 Elaine M. Murphy et al., "Was the "ABC" Approach (Abstinence, Being Faithful, Using Condoms) Responsible for Uganda's Decline in HIV?' 3 (9) PLoS Med. (2006): 1-5.

132 The ABC Approach, supra, note 91, at p. 18.

133 Ibid.

134 Although the number of people living with HIV increased in 2008, this in part is attributed to increased longevity stemming from improved access to HIV treatment. See UNAIDS and WHO, supra, note 13.

135 Ibid.

136 Ibid. 
and 91 percent of HIV infection among children, with 72 percent of the world's AIDS-related deaths. ${ }^{137}$ However, the governments of African countries seeing a decline should be applauded for having funneled money into their national AIDS programs. For example, South Africa, in 2012, invested \$1.9 billion from public sources in its national AIDS response, Kenya doubled its domestic investments for AIDS between 2008 and 2010, and Togo did the same between 2007 and 2010. ${ }^{138}$ International assistance has also been stable, with 26 of the 33 countries in SubSaharan Africa relying on donor support for their domestic programs. ${ }^{139}$

It is indeed obvious that the flexibilities contained in the TRIPS Agreement, and as endorsed by the Doha Declaration, provide great opportunities for WTO members to reduce the cost of and increase access to antiretroviral drugs, thereby lowering HIV/AIDS prevalence and deaths. The examples of Zambia and Mozambique using compulsory licenses on patents to get relevant HIV medicines at lower costs for its citizens is a clear illustration that WTO and TRIPS could be helpful in curbing the disease and thus contribute to the success story.

PEPFAR has also been instrumental in the decline of HIV/AIDS in Africa. As the largest health initiative undertaken by one country to address the disease, PEPFAR increased the number of Africans receiving ART from 50,000 at the start of the initiative in 2004, to about 1.2 million in 2008. According to a 2009 study published in the Annals of Internal Medicine, the program averted about 1.1 million deaths in Africa and reduced the death rate due to AIDS in the countries by 10 percent. Antiretroviral treatment for HIV positive individuals has been the hallmark of the world's response to the AIDS pandemic. This effort cannot be undermined when looking at the success results in Africa today.

Strong governmental political leadership is essential in combatting AIDS, as seen in the case of Uganda. Uganda had strong political leadership, pioneered approaches to reducing stigma, and has brought discussion of sexual behavior out into the open. They involved HIV-infected people in public education, persuaded individuals and couples to be tested and counseled, improved the status of women, involved religious organizations, and enlisted traditional healers, among other methods. ${ }^{140}$ Uganda could be said to have promoted the 'A through $Z$ ' means to prevent AIDS, ${ }^{141}$ and this has and is being emulated in various forms in other African countries.

Although progress has been made in curbing the prevalence of HIV/AIDS, treatment coverage in Sub-Saharan Africa is far from the 80 percent universal access goal. Given that new infections outpace those starting treatment, prevention remains pivotal to an effective AIDS response. There is still more to be done, and the African governments and the international community must not let down its guard because of the mild but significant progress made in some African countries.

137 Ibid.

138 Jocelyn Sambia, 'New HIV Infections are Falling Dramatically in Africa,' Botswana Gazette, January 2013.

139 Ibid.

140 The ABC Approach, supra, note 91, at p. 22.

141 Ibid. 